\title{
Mycoplasma bovis Infections-Occurrence, Diagnosis and Control
}

\author{
Katarzyna Dudek ${ }^{1, *(\mathbb{D},}$, Robin A. J. Nicholas ${ }^{2}$, Ewelina Szacawa ${ }^{1}$ () and Dariusz Bednarek ${ }^{1}$ \\ 1 Department of Cattle and Sheep Diseases, National Veterinary Research Institute, 57 Partyzantów Avenue, \\ 24100 Pulawy, Poland; ewelina.szacawa@piwet.pulawy.pl (E.S.); dbednarek@piwet.pulawy.pl (D.B.) \\ 2 The Oaks, Nutshell Lane, Farnham, Surrey GU9 0HG, UK; robin.a.j.nicholas@gmail.com \\ * Correspondence: katarzyna.dudek@piwet.pulawy.pl
}

Received: 30 June 2020; Accepted: 4 August 2020; Published: 6 August 2020

\begin{abstract}
Mycoplasma bovis is a cause of bronchopneumonia, mastitis and arthritis but may also affect other main organs in cattle such us the eye, ear or brain. Despite its non-zoonotic character, M. bovis infections are responsible for substantial economic health and welfare problems worldwide. M. bovis has spread worldwide, including to countries for a long time considered free of the pathogen. Control of $M$. bovis infections is hampered by a lack of effective vaccines and treatments due to increasing trends in antimicrobial resistance. This review summarizes the latest data on the epizootic situation of $M$. bovis infections and new sources/routes of transmission of the infection, and discusses the progress in diagnostics. The review includes various recommendations and suggestions which could be applied to infection control programs.
\end{abstract}

Keywords: Mycoplasma bovis; cattle; disease; prevalence; control

\section{Introduction}

In 2017, New Zealand became the last of the major cattle-rearing countries to be infected with Mycoplasma bovis [1]. Finland had also remained free until relatively recently but became infected via imported cattle in 2012 [2]. Undoubtedly, M. bovis is now the most important mycoplasma of livestock being a primary cause of mastitis, arthritis, keratoconjunctivitis and other disorders as well as a major player in the bovine respiratory disease complex (BRD) [3]. Previously Mycoplasma mycoides subsp. mycoides, the aetiological agent of the World Organisation for Animal Health (OIE)-listed contagious bovine pleuropneumonia, had this dubious distinction but this mycoplasma is now confined to countries in sub Saharan Africa.

Mycoplasma bovis was first reported in the USA in 1961 from a case of bovine mastitis then was probably exported in cattle of high genetic quality to Israel [3]. It then spread around the world, reaching the UK and the rest of Europe in the mid1970s (Figure 1). International trade in cattle and cattle products like semen has enabled its silent spread to all continents where cattle are kept. The date of isolation in a particular country, of course, is not necessarily the date of introduction even in the USA as mycoplasmas were very much an unknown quantity and their fastidious nature made isolation and detection an extremely difficult task. Indeed, it has only been in the last two decades with the introduction of DNA amplification techniques that detection and identification have become routine in many parts of the world. However, not all countries have veterinary diagnostic laboratories which can identify these organisms. 


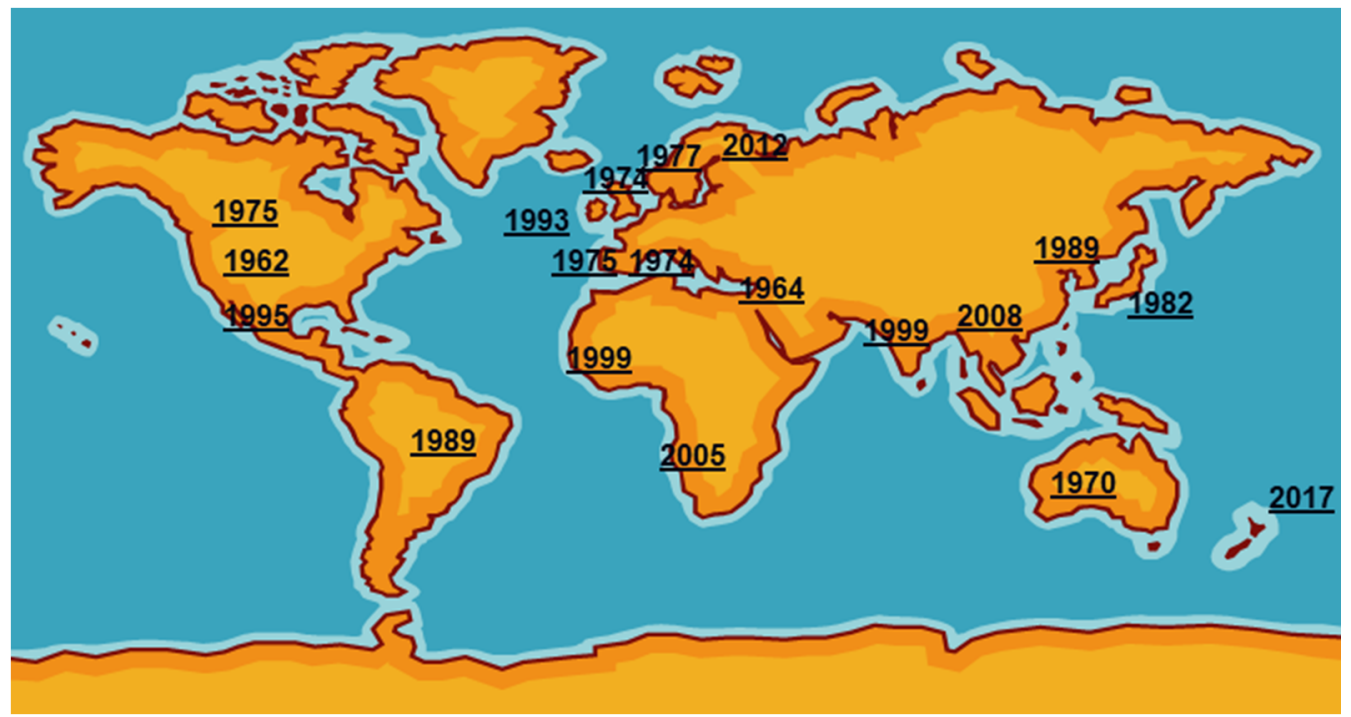

Figure 1. First detections of Mycoplasma bovis around the world.

Initially the importance of $M$. bovis, particularly in BRD, was underestimated because of the promotion of more established and easier detectable organisms like the bacteria Mannheimia haemolytica, Histophilus somni and Pasteurella multocida and viruses, namely bovine respiratory syncytial disease, parainfluenza-3 virus, bovine herpesviruses, coronaviruses and bovine viral diarrhoea virus. The presence of $M$. bovis in healthy cattle, although at a much lower levels than infected ones, delayed recognition of its pathogenicity. Once the importance of environmental factors such as weather, variation in strain virulence and its interaction with the BRD pathogens were known, studies quickly demonstrated its widespread prevalence in pneumonic calves and, later, older cattle.

Despite attempts going back nearly half a century, control of $M$. bovis diseases is still problematic because of a lack of an effective commercial vaccine. Many have been marketed, particularly in the USA, but little data exist to assess their immunogenicity and protective properties [4]. To be valuable they are required to be part of multivalent vaccines incorporating the causative bacteria and viruses currently available for BRD. Presently, no vaccine is available for mycoplasma mastitis, a major problem in large dairy herds of North America where they are often untreatable. Indeed, the major trend in the last two decades has been the alarming decrease in susceptibility of M. bovis to the commonly used antimicrobials including the fluoroquinolones [5].

This review summarizes the latest data on the epizootic situation of $M$. bovis infections and new sources/routes of transmission of the infection and discusses the progress in diagnostics. The review also covers aspects related to $M$. bovis infection control, collecting various recommendations and suggestions which could be applied in the infection control programs.

\section{Mycoplasma bovis: Key Facts}

Mycoplasma bovis (M. bovis) is most often considered to cause caseonecrotic pneumonia, mastitis and arthritis [6,7]. However, cases of infectious keratoconjunctivitis, suppurative otitis media, meningitis, decubital abscesses, endocarditis and reproductive disorders have been associated with M. bovis [7-10]. Most importantly M. bovis is one of the causes of BRD with other aetiological agents, both bacterial and viral $[11,12]$.

M. bovis is one of 13 species of mycoplasmas diagnosed in cattle; however, not all of them cause serious diseases, and some may even constitute normal flora of the bovine respiratory tract. For example, the most important mycoplasma in bovine severe respiratory diseases is the previously mentioned Mycoplasma mycoides subsp. mycoides. Mycoplasma bovigenitalium is generally associated with bovine reproductive disorders, while Mycoplasma bovoculi has been isolated from infectious keratoconjunctivitis in cattle [3]. M. bovis infections are non-zoonotic; however, substantial economic and cattle health and 
welfare impacts are felt worldwide [3]. M. bovis affects all age groups of cattle (prewean, postwean, neonate and adult) and all cattle sectors such as beef, milk or rearing [3]. M. bovis can persist in a herd for very long periods of time, with the possibility of pathogen shedding by the infected animals for a few weeks to several months $[13,14]$. The evolutionary absence of a cell wall in principle makes M. bovis resistant to penicillins and cephalosporins [3,4]. Moreover, in vitro studies on $M$. bovis field isolates show increasing trends in antimicrobial resistance, including tetracyclines and even newer generation macrolides considered effective against $M$. bovis infections [5,15-18]. M. bovis infections are usually characterized by chronic course and are difficult to treat successfully [3]. One recent in vivo study has shown an efficacy of treatment of the $M$. bovis pneumonia in calves using enrofloxacin given alone, unlike the combination therapy with co-administration of flunixin meglumine, a nonsteroidal anti-inflammatory drug or pegbovigrastim (immunostimulator), which rather exacerbated the disease. However, it should be remembered that fluoroquinolones, although effective in this case, should be used as antimicrobials of last resort [19]. Some experimental M. bovis vaccines have been shown to be immunogenic and protective; however, currently no commercial vaccines are available in Europe with only some autogenous vaccines in use in the United States and Great Britain [20-22].

\section{Current Reports on the Epizootic Situation of M. bovis}

It was previously reported that $M$. bovis has the ability to spread worldwide to countries for a long time considered free of the pathogen because of the widespread international trade in cattle $[2,23,24]$. The first case of M. bovis infection in Finland was recorded relatively recently in 2012 in pneumonic calves. In 2012-2015, 0.26\% of Finnish dairy farms were M. bovis infected [2]. To date, it is estimated that only $0.8 \%$ of Finnish dairy herds were infected with M. bovis between 2012 and 2018 [23]. A two-year survey included 19 Finnish dairy farms previously free of $M$. bovis showed mastitis caused by M. bovis in over $89 \%$ of all farms tested; however, only a few clinical mastitis cases were seen. In the remaining two farms, no M. bovis mastitis cases were detected during the study period; calf pneumonia caused by $M$. bovis were, however, observed. In this study, the results may indicate a rather subclinical course of mastitis due to M. bovis infection. Additional data including M. bovis antibody detection using the MilA ELISA showed the majority of cows were positive for $M$. bovis throughout the study period, regardless of the infection status of the farm. It confirms that $M$. bovis may circulate for long time in the herd [23].

The detection of $M$ bovis in New Zealand was remarkable for several reasons. First, New Zealand was probably the last major cattle-rearing nation to become infected; secondly, it does not import cattle, the main route of cross border infection, and had not done so for nearly a decade; and thirdly, New Zealand took the unprecedented decision to eradicate the organism from its cattle industry despite the fact the clinical disease was overwhelmingly mild. M. bovis was first detected in a dairy herd at the Bay of Plenty on the South Island in 2017. Since this isolation, up until June 2020, just over 1800 farms have been affected, involving the slaughter of nearly 160,000 cattle at a cost of NZ\$203 million (about 116 million euros). With just over 250 farms still affected, complete eradication looks feasible but challenging and would be a first amongst cattle rearing countries. The origins of the outbreaks have still not been definitively traced but whole genome sequencing of 171 isolates from 30 infected herds indicated that the current outbreak was probably caused by recent entry of M. bovis, perhaps 1-2 years before detection, from a single source either as a single entry of a single $M$. bovis clone or, potentially, up to three entries of three very closely related $M$. bovis clones from the same source [25]; this suggests that there were probably several simultaneous outbreaks strongly implicating infected imported semen. Indeed M. bovis DNA was detected by PCR in one batch of semen but unfortunately could not be isolated. While analyses to date have not identified the source, the most closely related international isolates that have been characterised are European in origin [25].

Interesting information can be gathered by estimating on-farm/within-herd prevalence of $M$. bovis infections $[26,27]$. Such a repeated cross-sectional six-month study on $M$. bovis intramammary infections was conducted between 2017 and 2018 in four Estonian dairy herds with previously confirmed M. bovis positive status. The qPCR results of examination of pooled cow composite milk samples in the 
four endemically infected herds showed a differential and relatively low within-herd prevalence, which ranged between $0.4 \%$ and $12.3 \%$. For the author, this could be a result of the different infection phases, $M$. bovis strain differentiation, intermittent shedding of the pathogen by the infected cows or low concentration of M. bovis in the examined milk samples. Similar prevalence (3.7-11\%) was observed in clinical cases of mastitis due to $M$. bovis during a six-month study period in the four dairy herds. Additional evaluation of pooled cow colostrum samples during the same study period also showed low prevalence of $M$. bovis in the study herds ranging between $1.7 \%$ and $4.7 \%$ [26].

Within-herd prevalence of $M$. bovis DNA in cow colostrum samples was also estimated in 2016-2017 in seventeen Belgian herds with a recent infection of M. bovis. This survey was performed on dairy, beef and mixed-dairy farms with $M$. bovis positive status diagnosed less than one month before sample collection. The herds were additionally divided into two groups, depending on whether the infection was confirmed only in calves or in both calves and adult animals. The results showed only seven colostrum samples positive for M. bovis DNA originated from four herds, which was $1.9 \%$ of the total number of samples tested. In the positive farms on-farm/within-herd prevalence ranged between $2.8 \%$ and $30.0 \%$, whereas the average within-herd prevalence estimated for all seventeen herds tested was $3.2 \%$. According to the author, the reason for such low average within-herd prevalence of M. bovis DNA obtained in this survey was probably a result of differentiation in the infection phases in the periparturient cows or false positive results of real-time PCR assays used in M. bovis DNA detection particularly due to the possibility of ongoing co-infections with other Mycoplasma species [27]. In 2009, it was reported that $1.5 \%$ of all herd tested had bulk tank milk samples positive for $M$. bovis confirmed by culturing and PCR [28].

Data collected in Great Britain between 2006 and 2017 including diagnoses of respiratory disease, mastitis and arthritis due to $M$. bovis infections demonstrated a significant proportion of pneumonia $(86.4 \%)$, which showed an increasing trend since 2014 . The highest number of pneumonia incidents was diagnosed in 2017 (over 120 diagnoses), reaching 7.5\% of all diagnosable submissions. For comparison, the annual cases of arthritis and mastitis for all the examined years were less than 30 per year, with a slight predominance for mycoplasma mastitis. In this survey the incidents of $M$. bovis pneumonia were diagnosed mainly in the postwean age group of calves. However, since 2012, the number of pneumonia diagnoses in the preweaning calves was comparable. The smallest number of $M$. bovis pneumonia cases was diagnosed in the neonate age group of calves. Seasonal data collected from 2006 to 2017 showed the largest number of respiratory diagnoses due to M. bovis were in the colder seasons, i.e., between October and March, which could be caused not only by temperature fluctuations, but also by closer contact of animals in the herd during housing [20,24]. Temperature fluctuations are probably related to stress accompanied by elevated blood corticosteroid concentrations, which may consequently predispose calves to M. bovis infection, as confirmed in both in vivo and in vitro studies using dexamethasone [29-31]. In the remaining months, i.e., from July to September, and from April to June, the respiratory submissions were comparable, although slightly higher in the spring months. Additional examinations also showed a higher incidence of $M$. bovis respiratory disease in the beef sector of cattle (almost $42 \%$ ). Another slightly less affected cattle sector was dairy with $32.8 \%$ of $M$. bovis respiratory submissions [20]. A previous study performed in Great Britain between 1990 and 2000 showed that over $50 \%$ of a total of 1413 cattle isolates tested were M. bovis, mostly originating from pneumonia cases. M. bovis was also isolated from mastitis cases, joint fluid, eyes and sporadically from sheath washings, urogenital tract and heart blood [32].

The problem of subclinical intramammary infections with $M$. bovis as a consequence of recent clinical mastitis outbreaks in four Australian dairy herds was discussed in the study of Hazelton et al., which concluded that an early diagnosis of such cases may consequently prevent the future spread of M. bovis in the herd [13]. The apparent cow-level prevalence of $M$. bovis intramammary infections in these herds was determined immediately after cessation of outbreaks. Before the herd sampling between 2014 and 2016 all clinically affected cows due to $M$. bovis were culled. From a total of 2232 cows located in the main milking group of each herd from which 88 initial pooled milk samples were 
collected, only two M. bovis PCR positive cows were detected, which constituted less than $1 \%$ of average apparent cow-level prevalence of subclinical intramammary M. bovis infection. Additional tests performed individually on 15 cows located in the hospital group of each herd and M. bovis suspected gave five positive PCR results. M. bovis DNA was also detected by PCR in bulk tank milk collected from two study herds. However, in 6 out of 1813 cows from three study herds, M. bovis was isolated using microbiological culture. Five positive culture results were detected in cows located in the hospital group and M. bovis suspected, whereas the remaining one was from the main milking group, both within the same herd. For information, the culture positive cow in the main milking group had also positive $M$. bovis PCR result. In addition, $M$. bovis was isolated from bulk tank milk sampled from one study herd; however, it was not the same herd from which $M$. bovis culture positive cows were detected. To estimate $M$. bovis seroprevalence in the four study herds, a total of 199 sera were collected from 50 cows located in the main milking group of each herd, with the exception of one herd from which 49 results were estimated. The results showed the average $M$. bovis seroprevalence of $38 \%$, which varied from $16 \%$ to $76 \%$. It is also worth mentioning that in two of the four herds tested, several months after the herd sampling, new clinical cases or positive results in the hospital group bulk tank were reported, both confirmed by M. bovis PCR [13].

\section{Disease Course and Source of $M$. bovis Infection}

M. bovis infections occur with various clinical manifestations, such as pneumonia, mastitis, arthritis, otitis, keratoconjunctivitis, meningitis, endocarditis and others, the most important of which are summarized in Table 1. The clinical picture of respiratory disease diagnosed as M. bovis is not usually characteristic and often does not differ from clinical signs caused by infections with other bovine respiratory tract pathogens, especially in the presence of co-infections [20]. The study on feedlot beef calves showed that $M$. bovis was isolated from all diagnosed pneumonia categories, such as caseonecrotic bronchopneumonia, both caseonecrotic and fibrinosuppurative bronchopneumonia or fibrinosuppurative bronchopneumonia alone. In this study distinct synergism in pneumonia cases between $M$. bovis and Pasteurellaceae family pathogens, especially for M. haemolytica, was demonstrated. Both pathogens were identified in focal coagulative necrosis lesions within lung tissues [33].

In cases of keratoconjunctivitis as well as brain disorders, $M$. bovis infections, which are often overlooked in the differential diagnosis of these diseases, should be taken into account (Table 1).

As recently reported, both clinical and subclinical courses of mastitis due to $M$. bovis infection were detected $[13,23]$. However, the possibility of subclinical intramammary infections with $M$. bovis as a consequence of the recent clinical mastitis outbreaks should be considered as previously presented in the Section 3 in the study of Hazelton et al. [13].

It was first recognized that $M$. bovis-positive semen used in artificial insemination was a cause of mastitis outbreak in two naive dairy herds, despite high biosecurity and good farming practice carried out on these farms [2]. Out of the total of ten bulls used to inseminate cows with M. bovis mastitis diagnosed, only one of them appeared to be the M. bovis carrier. Additionally, only one of the cows from each herd that were inseminated with the contaminated processed semen from the same bull developed mastitis. In both study herds, the infection not only transmitted to other cows that were not inseminated with $M$. bovis-positive semen, but also to calves. The core-genome multilocus sequence typing (cgMLST) analysis of M. bovis strains isolated from the mastitis cases and the bull semen clustered together [2]. 
Table 1. Examples of clinical manifestations of $M$. bovis infections. The sequence presented is consistent with the frequency of each clinical manifestation from the most to the least frequently diagnosed cases in cattle.

\begin{tabular}{|c|c|c|c|c|c|}
\hline $\begin{array}{l}\text { Course of M. bovis } \\
\text { Infection }\end{array}$ & $\begin{array}{c}\text { Type of Research } \\
\text { (Experimental/Survey) }\end{array}$ & Cattle Sector & Main Clinical Signs/Lesions/Subclinical & $\begin{array}{l}\text { Methods Used for the Infection } \\
\text { Confirmation/Presence }\end{array}$ & Reference \\
\hline \multirow[b]{2}{*}{ pneumonia } & survey & beef & $\begin{array}{l}\text { caseonecrotic bronchopneumonia; } \\
\text { fibrinosuppurative bronchopneumonia }\end{array}$ & IHC; PCR & [33] \\
\hline & experimental & dairy-cross & $\begin{array}{l}\text { nasal discharge; coughing; caseonecrotic } \\
\text { pneumonia }\end{array}$ & $\begin{array}{l}\text { ELISA for M. bovis antigen detection; } \\
\text { IHC; ELISA for specific antibody } \\
\text { detection }\end{array}$ & [19] \\
\hline \multirow{2}{*}{ mastitis } & survey & \multirow{2}{*}{ dairy } & clinical mastitis; subclinical mastitis & $\begin{array}{l}\text { culture; real-time PCR; two different } \\
\text { ELISAs for specific antibody detection } \\
\text { (MilA IgG ELISA; BioX ELISA) }\end{array}$ & [23] \\
\hline & survey & & clinical mastitis; subclinical mastitis & $\begin{array}{l}\text { culture; PCR; } \\
\text { ELISA for specific antibody detection }\end{array}$ & [13] \\
\hline \multirow[b]{2}{*}{ arthritis } & survey & beef & arthritis; tenosynovitis & culture; passive hemagglutination test & [33] \\
\hline & experimental & dairy & $\begin{array}{l}\text { joint swelling; lameness/fibrinosuppurative } \\
\text { synovitis and tenosynovitis; thrombus presence }\end{array}$ & culture; indirect hemagglutination test & [34] \\
\hline \multirow[b]{2}{*}{ otitis } & survey & dairy & ear droop; otic exudate & $\begin{array}{l}\text { ELISA for specific antibody detection; } \\
\text { DGGE }\end{array}$ & [35] \\
\hline & survey & beef & $\begin{array}{l}\text { ear droop; exudative otitis media; facial } \\
\text { paralysis; occasionally nasal exudate; } \\
\text { nystagmus, head tilt, ataxia/suppurative lesions } \\
\text { in the middle ear; lung consolidation (most } \\
\text { cases); cerebellar meningitis (some cases) }\end{array}$ & $\begin{array}{l}\text { culturing; immune-peroxidase test; PCR; } \\
\text { IHC; transmission electron microscopy }\end{array}$ & [7] \\
\hline kerato-conjunctivitis & survey & beef & "pink eye" signs & $\begin{array}{l}\text { culture; RAPD; PCR-RFLP; DNA } \\
\text { sequencing }\end{array}$ & [8] \\
\hline \multirow{2}{*}{ brain disorders } & \multirow{2}{*}{ survey } & \multirow{2}{*}{ dairy } & $\begin{array}{l}\text { head tilt; central nervous system signs/purulent } \\
\text { meningitis }\end{array}$ & ELISA for specific antibody detection & \multirow[t]{2}{*}{ [36] } \\
\hline & & & $\begin{array}{l}\text { lethargy, blindness; teeth grinding/cerebral } \\
\text { hemisphere necrosis }\end{array}$ & enrichment and capture ELISA & \\
\hline endocarditis & survey & beef & no clinical signs; caseated lesions in the heart & $\begin{array}{l}\text { culture; } u v r C \text { gene PCR; loop-mediated } \\
\text { isothermal amplification assay; IHC }\end{array}$ & [10] \\
\hline
\end{tabular}


The role of airborne transmission of $M$. bovis is unclear with little experimental evidence supporting this route of infection $[37,38]$. In response to exposure of calves to aerosolized M. bovis, respiratory disease was induced. In the infected calves, specific $M$. bovis lung lesions confirmed by necropsy and histological examinations were observed despite the lack of clinical signs. However, re-isolation of $M$. bovis from the upper trachea in most infected calves was additional confirmation of this infection route [37].

Recent reports on M. bovis indicated colostrum as a possible source of infection based on positive results for M. bovis DNA [26,27]. Additionally, in one of these studies, herd-specific M. bovis strains were isolated from cows with clinical mastitis and calves affected with respiratory disease showing possible transmission of the pathogen between dairy cows and calves via contaminated milk. However, in this study other routes of $M$. bovis infection transmission like direct/indirect contact between animals within the study herds, animal handling or air-borne route cannot be excluded [26]. The most important sources of $M$. bovis infection/routes of $M$. bovis infection transmission are summarized in Table 2 . Other no less important sources/routes of $M$. bovis infection transmission not included in the Table 2 such as nose-to-nose contact between animals or fomites (e.g., farm-personnel's contaminated hands, equipment), although difficult to directly prove or document, should also be considered $[26,39,40]$.

Within the host, $M$. bovis disseminates by the haematogenous route, which may result in subsequent lesions in organs other than those initially affected. In one such study all diagnosed cases of arthritis in feedlot beef calves were accompanied by lung lesions, which accounted for nearly $50 \%$ of all diagnosed M. bovis-related pneumonias. The arthritis cases were probably of pulmonary origin [33]. In post-mortem findings in M. bovis affected calves, both meningitis and otitis media/interna were diagnosed. In other calf necropsy examinations, necrosis within the brain and fibrinous heart lesions due to M. bovis infection were evident [36]. The ability of M. bovis to spread within different organs of the same host was previously confirmed [7]. In the majority of calves diagnosed with suppurative otitis media severe lung lesions were observed. In some of them cerebellar meningitis was also diagnosed. Additionally, in some calves, $M$. bovis antigen was identified in the temporal bone, liver and kidney [7]. 
Table 2. Examples of sources of $M$. bovis infection/routes of $M$. bovis infection transmission.

\begin{tabular}{|c|c|c|c|c|c|}
\hline $\begin{array}{l}\text { Source of Infection/Route of } \\
\text { Infection Transmission }\end{array}$ & $\begin{array}{c}\text { Type of Research } \\
\text { (Experimental/Survey) }\end{array}$ & Cattle Sector & $\begin{array}{c}\text { Number of } \\
\text { Herd/Farms Tested }\end{array}$ & $\begin{array}{l}\text { Methods Used for the Infection } \\
\text { Confirmation/Detection }\end{array}$ & Reference \\
\hline \multirow[b]{2}{*}{ colostrum } & survey & dairy & 4 & qPCR & [26] \\
\hline & survey & $\begin{array}{c}\text { dairy, beef and } \\
\text { dairy-mixed }\end{array}$ & 17 & real-time PCR & [27] \\
\hline milk & survey & dairy & 4 & $\begin{array}{c}\text { qPCR; } \\
\text { culturing; } \\
\text { core-genome multilocus sequence } \\
\text { typing (cgMLST) }\end{array}$ & [26] \\
\hline semen & survey & dairy & 2 & $\begin{array}{c}\text { culturing; } \\
\text { real-time PCR; } \\
\text { WGS; } \\
\text { cgMLST analysis }\end{array}$ & [2] \\
\hline air-borne & experimental & dairy-cross & not applicable & $\begin{array}{c}\text { culturing; } \\
\text { polC PCR; } \\
\text { MilA IgG ELISA; } \\
\text { post mortem examination; } \\
\text { histopathological examination }\end{array}$ & [37] \\
\hline intrauterine & survey & dairy & not described & $\begin{array}{l}\text { culturing; } \\
\text { IHC; } \\
\text { ISH }\end{array}$ & [41] \\
\hline
\end{tabular}




\section{Currently Used Diagnostic Methods}

The clinical signs of infections in cattle associated with $M$. bovis are non-specific; for that reason, sensitive, accurate and rapid testing of animals is needed for reliable diagnosis. Culturing of $M$. bovis is a gold standard method but is time-consuming and requires specific conditions. Different kinds of media are widely used in experimental studies and in confirmation of infection caused by M. bovis, and include Hayflick's [42], modified PPLO [43] and Eaton's [44]. Mycoplasmas are fastidious, slow growing and can be easily overgrown by other bacteria. During the last few years various tests have been used for the detection of $M$. bovis infections in cattle (Table 3). 
Table 3. The characteristics of recently developed methods for M. bovis detection in various specimens from cattle.

\begin{tabular}{|c|c|c|c|c|c|}
\hline Assay/Target & Samples & Limit of Detection & Sensitivity & Specificity & Reference \\
\hline real-time PCR/uvrC & $\begin{array}{l}\text { lung samples }(\mathrm{n}=30) \\
\text { milk samples }(\mathrm{n}=21)\end{array}$ & $\begin{array}{c}100 \text { fg DNA; } \\
40 \text { genome copies/reaction; } \\
250 \mathrm{CFU} / \mathrm{mL}\end{array}$ & $\begin{array}{l}10^{3} \text {-fold more } \\
\text { sensitive than } \\
\text { conventional PCR }\end{array}$ & $\begin{array}{c}100 \% \\
\text { (evaluated for } 6 \text { Mycoplasma spp. } \\
\text { and } 6 \text { species of bacteria) }\end{array}$ & [45] \\
\hline $\mathrm{qPCR} / u v r \mathrm{C}$ & deep nasopharyngeal swabs $(\mathrm{n}=208)$ & $1.61 \times 10^{2} \mathrm{CFU} / \mathrm{mL}$ & $100 \%$ & $87.27 \%$ & [46] \\
\hline $\mathrm{qPCR} / g l t \mathrm{X}$ & $\begin{array}{l}\text { milk samples from individual } \\
\text { quarters }(\mathrm{n}=9) ; \\
\text { bulk tank milk samples }(\mathrm{n}=59)\end{array}$ & $\begin{array}{c}10-100 \text { genome } \\
\text { equivalents } / \text { reaction; } \\
1 \times 10^{4}-1 \times 10^{5} \text { cells } / \mathrm{mL}\end{array}$ & $100 \%$ & $\begin{array}{c}94.4 \% \\
\text { (evaluated for } 3 \text { Mycoplasma spp.) }\end{array}$ & [47] \\
\hline $\begin{array}{c}\text { real-time multiplex PCR } \\
\text { M. bovis/uvrC } \\
\text { M. californicum/rpoB } \\
\text { M. bovigenitalium/16S-23S } \\
\text { rRNA }\end{array}$ & $\begin{array}{c}\text { swab samples }(\mathrm{n}=95) \\
\text { semen samples }(\mathrm{n}=44) \\
\text { individual milk samples }(\mathrm{n}=114) \\
\text { bulk tank milk samples }(\mathrm{n}=221)\end{array}$ & $\begin{array}{c}1.3 \times 10^{2}-1.3 \times 10^{7} \\
\mathrm{CFU} / \mathrm{mL}\end{array}$ & not applicable & $\begin{array}{c}100 \% \\
\text { (evaluated for } 10 \text { Mycoplasma spp. } \\
\text { and } 11 \text { species of bacteria) }\end{array}$ & [48] \\
\hline $\begin{array}{c}\text { multiplex qPCR Pneumo } \\
\text { 4B/M. bovis } \\
\text { M. haemolytica } \\
\text { P. multocida } \\
\text { H. somni }\end{array}$ & tracheal aspirate samples $(n=176)$ & $\begin{array}{c}10 \text { genome copies; } \\
1.1-3.3 \log _{10} \text { CFU/0.5 mL }\end{array}$ & 0.96 & $\begin{array}{c}0.71 \\
\text { (evaluated for 6 Mycoplasma spp. } \\
\text { and 66 species of bacteria) }\end{array}$ & [49] \\
\hline $\begin{array}{l}\text { multiplex qPCR } \\
\text { Mastit 4/M. bovis } \\
\text { Staphylococcus aureus } \\
\text { Streptococcus agalactiae } \\
\text { Streptococcus uberis }\end{array}$ & milk samples & - & - & - & [26] \\
\hline $\begin{array}{l}\text { real-time multiplex } \\
\text { RPA/M. bovis/uvrC } \\
\text { M. haemolytica/nmaA }\end{array}$ & deep nasopharyngeal swabs $(n=100)$ & 40 genome copies/reaction & - & $\begin{array}{c}98.0 \\
\text { (evaluated for } 10 \text { Mycoplasma spp. } \\
\text { and 35 species of bacteria) }\end{array}$ & [50] \\
\hline $\begin{array}{l}\text { real-time multiplex PCR } \\
\text { PathoProof }{ }^{\mathrm{TM}} \text { Mastitis } \\
\text { Major } 4.2 / M \text {. bovis } \\
\text { Staphylococcus aureus } \\
\text { Streptococcus agalactiae } \\
\text { Streptococcus uberis }\end{array}$ & milk samples & - & - & - & [13] \\
\hline
\end{tabular}


Table 3. Cont.

\begin{tabular}{|c|c|c|c|c|c|}
\hline Assay/Target & Samples & Limit of Detection & Sensitivity & Specificity & Reference \\
\hline $\begin{array}{l}\text { real-time PCR VetMAX } \\
\text { M. bovis }\end{array}$ & $\begin{array}{c}\text { tissue samples, bronchoalveolar } \\
\text { lavage fluid samples, synovial fluid, } \\
\text { milk samples }\end{array}$ & 10 genome copies/reaction & $100 \%$ & $\begin{array}{c}\text { 100\% (evaluated for } 50 \text { other } \\
\text { bacteria species, including } \\
\text { M. agalactiae, } \\
\text { Streptococcus uberis and } \\
\text { Streptococcus dysgalactiae }\end{array}$ & [27] \\
\hline $\mathrm{LAMP} / u v r \mathrm{C}$, gyr $\mathrm{B}$ & milk samples from 95 dairy farms & $5 \times 10^{1} \mathrm{CFU} / \mathrm{mL}$ & $96.8 \%-100 \%$ & $\begin{array}{c}94.7 \%-100 \% \\
\text { (evaluated for } 2 \text { Mycoplasma spp. } \\
\text { and } 4 \text { species of bacteria) }\end{array}$ & [51] \\
\hline LAMP/oppD & $\begin{array}{l}\text { milk samples from individual } \\
\text { quarters }(\mathrm{n}=9) ; \\
\text { bulk tank milk samples }(\mathrm{n}=59)\end{array}$ & $\begin{array}{c}10 \text { genome } \\
\text { equivalents/reaction; } \\
1 \times 10^{4} \text { cells } / \mathrm{mL}\end{array}$ & $87.5 \%$ & $\begin{array}{l}82.4 \% \text { (evaluated for } 3 \\
\text { Mycoplasma spp.) }\end{array}$ & [47] \\
\hline $\begin{array}{l}\text { PURE-LAMP } \\
\text { not applicable }\end{array}$ & $\begin{array}{l}\text { bulk tank milk samples }(\mathrm{n}=12) \\
\text { mature milk samples }(\mathrm{n}=73) \\
\text { colostrum/transitional milk samples } \\
(\mathrm{n}=74) ; \\
\text { mastitis milk samples }(\mathrm{n}=122)\end{array}$ & $>10^{2} \mathrm{CFU} / \mathrm{mL}$ of milk & $57.0 \%-97.0 \%$ & $\begin{array}{c}100 \% \\
\text { (evaluated for } 5 \text { Mycoplasma spp.) }\end{array}$ & [52] \\
\hline $\begin{array}{l}\text { RPA-LFD/uvrC, } \\
\quad o p p \mathrm{D}-o p p \mathrm{~F}\end{array}$ & $\begin{array}{l}\text { nasal swab samples }(\mathrm{n}=288) \\
\text { fresh lung samples }(\mathrm{n}=80) \\
\text { joint fluid samples }(\mathrm{n}=32) \\
\text { bulk tank milk samples }(\mathrm{n}=42)\end{array}$ & 20 genome copies/reaction & $99.0 \%$ & $\begin{array}{c}95.61 \% \\
\text { (evaluated for } 10 \text { Mycoplasma spp. } \\
\text { and } 13 \text { species of bacteria) }\end{array}$ & [53] \\
\hline MALDI-TOF MS & $\begin{array}{l}\text { culture-enriched bronchoalveolar } \\
\text { lavage fluid samples } \\
(\mathrm{n}=104)\end{array}$ & not applicable & $86.6 \%$ & $86.4 \%$ & [54] \\
\hline
\end{tabular}




\subsection{Real-Time PCR Assays for M. bovis Detection}

Detection of $M$. bovis by real-time PCR preceded by culture enrichment of the samples improves detection when DNA is present at low concentrations. Furthermore, a selective broth-enrichment step increases the probability of Mycoplasma recovery when compared to direct plating on agar [55]. In the real-time PCR assay [45], milk samples from dairies and lung tissue samples were culture-enriched in PPLO broth for $24 \mathrm{~h}$ before analysis. In another qPCR for M. bovis testing [46], the nasopharyngeal swabs were cultured for 3-5 days before the analysis. The molecular methods are optimized for the detection of M. bovis in nasopharyngeal swabs and milk samples, but they can be optimized to be used for the detection of $M$. bovis in different specimens [2,26,27,48,49]. In 2020, a qPCR was developed for the detection of $M$. bovis in tracheal aspirate samples derived from calves [49]. In research on $M$. bovis intramammary infection, the presence of this pathogen in colostrum and additionally in milk from clinical cases was assessed with qPCR [26]. It is also possible to detect M. bovis in processed semen $[2,48]$. The real-time PCR assays are characterised often by a low limit of detection (LOD) and specificity near to $100 \%$ [45-48]. Taking into consideration that the number of mycoplasmas that are shed during the infection is about $>1 \times 10^{6} \mathrm{CFU} / \mathrm{mL}$ in milk [4] and the LOD for real-time PCR for $M$. bovis detection in milk is $1.3 \times 10^{2} \mathrm{CFU} / \mathrm{mL}$ [48], the probability of the detection of infected cow in a herd is high. To assess the best sensitivity, the real-time PCR assays for M. bovis detection are usually used after an enrichment procedure of the samples. Additionally, centrifugation of the milk and plating the resuspended pellet of bacteria improves detection of mycoplasmas with culture. After such treatment, it was four times more likely to detect of a positive sample when compared to traditional culture regarding very small concentrations [56]. The combination of culture of viable bacteria and qPCR results enables the most accurate confirmation of active infection in animals.

\subsection{Fast and Cost-Effective Assays for M. bovis Detection}

Another approach for $M$. bovis detection is to design a simple and cost-effective assay run at a single temperature without the need of using specific equipment, which will be useful to process in developing countries. LAMP is recently of interest because it enables results to be received quickly, and the reaction is normally completed in less than $2 \mathrm{~h}$; furthermore, there is no need to have expensive laboratory equipment, as it is performed at a single temperature [57]. LAMP gives better results than qPCR when performed on purified DNA but is susceptible to contamination. Two assays, namely LAMP and qPCR developed for $M$. bovis detection in milk samples from individual cow quarters and bulk tank milk samples, accurately detected $M$. bovis isolates but gave false positive results for one Mycoplasma bovigenitalium isolate [47]. Another method called isothermal DNA amplification assay, a technique based on recombinase polymerase amplification (RPA) with lateral flow dipstick (LFD), allows one to obtain the result in $30 \mathrm{~min}$ and is dedicated for M. bovis DNA extracted directly from clinical samples i.e., nasal swabs, lungs tissue samples, joint fluids and bulk tank milk samples; no cross-reactions were observed with other Mycoplasma species [53]. Usually, LAMP assays are more sensitive than end-point PCRs, for example high sensitivity and specificity for all milk sample types was obtained with the use of LAMP combined with a procedure for ultra-rapid extraction (PURE-LAMP), in which various sample types i.e., bulk tank milk, mature milk, colostrum/transitional milk and mastitis milk were examined [52]. Similar parameters were obtained in LAMP for the examination of M. bovis in milk from mastitis cases [51].

\subsection{Immunohistochemistry and In-Situ Hybridization}

Although molecular methods are advantageous, they can only provide the data on M. bovis DNA, and there is lacking information about the presence of viable bacteria. Immunohistochemistry (IHC) and in-situ hybridization (ISH) are types of techniques which have the advantage that they are able to detect the localization of $M$. bovis antigen or DNA, respectively, in the examined tissue of the infected animals $[12,19,41,58,59]$. The IHC used in the study on calves experimentally infected with 
M. bovis allows one to detect $M$. bovis antigen in the bronchiolar epithelial cells in the lung tissue with histopathological changes that are characteristic for bronchiolitis [19]. Results of another experiment proved that $M$. bovis antigen was detected on the surface and inside the cytoplasm of bronchiolar epithelial cells in the pneumonic foci and in the cytoplasm of phagocytes at the margin of bronchiolar exudates [58]. In the study on aborted foetus and neonatal calf that were infected with M. bovis, its antigen was found with the use of IHC in the brain, liver, lungs and placenta of aborted foetus, and ISH showed the presence of its DNA i.e., in lungs and placenta of the examined animals [41]. The research on long-term survival of M. bovis in tissues of infected calves showed the persistence of this pathogen in necrotic lung lesions several weeks after the infection with the use of both methods [59]. It is also possible to examine the pulmonary samples of calves with BRD. IHC was used to detect the M. bovis antigen intralesional in different areas of the lungs [12]. However, while these techniques allow one to obtain significant information, they are also expensive and labour intensive and require trained staff.

\subsection{A Matrix-Assisted Laser Desorption/Ionization Time-of-Flight Mass Spectrometry for M. bovis Detection}

The matrix-assisted laser desorption/ionization time-of-flight mass spectrometry (MALDI-TOF MS) procedure has been applied to M. bovis detection. It was optimised for the detection of M. bovis isolates and found to be a suitable test for routine diagnostics in cattle, especially those from BRD cases. The protocol enables the identification of $M$. bovis from bronchoalveolar lavage fluid (BALF) after enrichment in culture. The higher number of positive samples was obtained after $72 \mathrm{~h}$ of enrichment. The main advantage of MALDI-TOF MS is that it only detects viable bacteria, which indicates that cattle have active rather than historic infections [54].

\subsection{Molecular Typing}

The analysis of M. bovis isolates with typing and sequencing methods can give additional information about their relationships and evolution. The multilocus sequence typing (MLST) analysis was proved to be suitable for molecular typing of $M$. bovis and the assessment of geographical relatedness of isolates. The MLST scheme based on eleven housekeeping genes was evaluated. Three genes, dnaN, metS and $h s p 70$, were taken for the sequence analysis and the remaining eight genes, i.e., $a d k, e f p, g m k, g y r B, p o l C, r p o B, t p i A$ and $u v r C$ were not chosen for the further analysis. It allows the acquiring of information on sequence variation, its type of distribution and disappearance of some sequence types [60]. A later study [61] assessed two MLST schemes for M. bovis isolate typing. The comparison of the performance of the two MLST schemes and additional identification of a new reference scheme capable of full typing of the examined isolates was made. The PubMLST reference method contains adh-1, gltX, gspA, gyrA, gyrB, pta-2, tdk and tkt locus; it is thought to be discriminatory and informative enough, but in this study, adh-1, one of the typing loci of $M$. bovis isolates, was missed. According to this reference scheme, the $a d h-1$ locus should be retired from the analysis. This approach was not beneficial for the study because the discrimination index received with the use of the six remaining PubMLST loci failed to reach the benchmark recommended for a reference method, and the addition of a seventh locus had to be made. The alternative scheme contains seven loci: $\operatorname{apt} A, \operatorname{dna} A$, $m e t S, r e c A, r p o D$, tkt and tufA. The comparisons of examined $M$. bovis genome sequences identified the $d n a A$ locus from the alternative scheme as the optimal replacement for $a d h-1$.

Another approach for epidemiological studies is the use of whole genome sequencing (WGS) to evaluate the molecular epidemiology and genomic diversity of $M$. bovis isolates as well as their genetic relationship. The single nucleotide polymorphism (SNP) analysis can be used to assess the intraspecies relationship and the presence of a dominant genotype that can be associated with one type of disease. This study is relevant to better understand the global epidemiology of this important pathogen and to assess control strategies [62]. Comparison of the M. bovis sequences can be used in assessing the genetic diversity of the strains [63] or to get the information about gene virulence [64]. 
WGS was used in New Zealand to track the outbreaks first identified in 2017. In all, 171 isolates from 30 infected herds have so far been sequenced, and results indicate that the current outbreak was probably caused by recent entry of the mycoplasma, perhaps 1-2 years before detection, from a single source either as a single border crossing of a single clone or, potentially, up to three border crossings of three very closely related clones from the same source (TAG 2019) probably in germplasm imported from Europe.

\subsection{Serological Approaches}

Serological diagnosis based on detection of specific antibodies to $M$. bovis is suitable and practical for the assessment of prevalence and epidemiological studies of herds [39]. Although serological testing is a reliable method for identification of infected animals, specific antibodies do not appear until 10 to 14 days after the infection but remain elevated for several months [65]. Various indirect ELISAs are used for anti-M. bovis antibody detection in cattle herds. The BIO K302 ELISA (BioX Diagnostics) was applied for evaluation of antibody response to $M$. bovis in serum and milk samples [13,66,67]. A study conducted in Belgium [67] showed that the ELISA is able to detect M. bovis specific antibodies in bulk tank milk up to 12 months after the outbreak of the disease. Researchers [66] examined bulk milk tank samples for all Danish herds with this ELISA and concluded that the cut-off value should be increased from $37 \%$, as suggested for animal-level diagnosis, to $50 \%$, to obtain more adequate sensitivity and specificity for bulk tank milk analysis. On the other hand, as a result of a European inter-laboratory comparison conducted on 180 serum samples, the sensitivity and specificity of BIO K302 ELISA was determined to be $49.1 \%$ and $89.6 \%$, respectively [68]. However, in 2020 it was confirmed that this ELISA was suitable for the serological evaluation of anti- $M$. bovis antibodies in longitudinal studies. Despite the low number of apparent clinical mastitis cases, it was useful in evaluation of M. bovis seroprevalence in dairy herds, which was on average $38 \%$ (16-76\%), as mentioned before [13].

Another indirect ELISA, made in-house and based on a fragment of a recombinant mycoplasma immunogenic lipase A (MilA), was developed [69]. This assay can be also useful for bulk tank milk sample analysis. The results of the presence of anti-M. bovis antibodies in bulk tank milk were positively correlated with the antibody detection in sera of the examined animals. Additionally, there was made a comparison between BIO K 260 (BioX Diagnostics) and the MilA ELISA [23], and the latter test gave a higher number of positive samples for $M$. bovis, and they were more convergent with those obtained with culture or real-time PCR. The obtained sensitivity and specificity for this test was $94.3 \%$ and $94.4 \%$, respectively. Additionally, it was shown that the MilA ELISA is also suitable for testing the presence of anti-M. bovis antibodies in the early stages of calf life (from the 3rd week of life) [70].

\subsection{Interlaboratory Trials of Diagnostic Tests}

M. bovis causes serious health problems in cattle herds almost all over the world, but its detection is not harmonised as yet and relies on different diagnostic methods, often in-house molecular techniques based on a variety of target genes and various different DNA extraction methods. There was conducted a European interlaboratory comparison of the diagnostic utility of the molecular tests for M. bovis detection [71]. Six laboratories from different countries were included in the study. Five different DNA extraction methods from bacterial culture and BALF samples were used. The molecular tests were made with the use of seven different PCR assays based on polC, oppD, uvrC and V4-V4 16S rRNA target genes. The comparison revealed that although the research used various assays, they had comparable diagnostic utility for $M$. bovis detection in cattle. The analytical specificity of the different PCR methods was comparable for all of the laboratories, except one, where $M$. agalactiae was detected because of the use of $16 \mathrm{~S}$ rRNA target gene. The LOD was from 10 to $10^{3}$ for the real-time, and from $10^{3}$ to $10^{6} \mathrm{CFU} / \mathrm{mL}$ for the end-point assays. According to the authors, this difference was acceptable. Cultures correctly detected the presence of $M$. bovis in bronchoalveolar lavage fluid samples and were consistent with PCR results. The recent comparison of diagnostic methods used in the different veterinary laboratories fortunately showed consensus. 


\subsection{Mixed Infections}

Other Mycoplasma spp. can also be associated with M. bovis infections in cattle. In BRD cases, most often M. dispar, M. canis and M. arginini are implicated [3,72]. In mastitis mycoplasmatica and reproductive disorders, M. bovigenitalium, M. californicum and M. alkalescens can also participate [73,74]. A test based on PCR with the 16SrRNA target gene and separation of the PCR products using denaturing gradient gel electrophoresis (PCR-DGGE) enabled the differentiation of 13 Mycoplasma spp. of bovine origin in mixed infections [75]. Traditionally, culture is used for the confirmation of BRD infections, but the incubation period for each examined bacterial pathogens is different and samples inoculated onto agar plates are often overgrown with other, fast growing bacteria. For that reason, the multiplex real-time PCRs used by the laboratories $[49,50,76]$ are the most suitable for simultaneous direct detection of $M$. bovis and other pathogens involved in BRD, such as P. multocida, M. haemolytica and H. somni, in contrast to methods not dedicated for different pathogen identification in mixed infections such as one-target PCR, traditional culture or MALDI-TOF MS [77]. When using one target PCR, there is no information about the involvement of other pathogens in the disease, different bacteria have various growth requirements and slow growing bacteria can be easily overgrown by others, and MALDI-TOF MS is not able properly detect all organisms from polymicrobial samples.

Various diagnostics methods for fast and accurate detection of M. bovis in various sample types and typing methods for identification and analysis of its strains in the last few years have been developed for evaluation of the disease course. Methods should be chosen according to the purpose of the survey, for herd-level testing or for individuals, or should be considered in terms of its usage for the specimen. The use of a combination of molecular, serological and culture-based methods is necessary for reliable diagnosis of diseases caused by this pathogen in cattle.

\section{Control-Recommendations for M. bovis Control Programs}

Due to the lack of efficient vaccines against $M$. bovis and increasing trends in antimicrobial resistance of $M$. bovis field isolates, it is important to provide consistent, possibly unified rules for effective control and/or eradication of $M$. bovis infections. However, in many ways, preventing the spread of $M$ bovis into healthy herds is relatively easy, as the screening of small numbers of cattle from source herds by serological tests, such as ELISA, can ensure that herds remain free of disease; this was successfully achieved in the Republic of Ireland when the national herd free of M. bovis was restocked following the BSE crisis [78]. Whether the Irish national herd is still free is unknown. However, few countries have active eradication plans for M. bovis, and because of its presence in all cattle-rearing countries, it is not subject to OIE regulations; indeed, it is very difficult for countries to impose trade restrictions when they themselves are infected. Israel has attempted to identify countries that export infected livestock into their country by mass screening between 2010-2011 and found cattle from Lithuania, Hungary and Australia to be highly seropositive [79].

Undoubtedly the most ambitious and unique plan for the complete eradication of $M$. bovis was made in New Zealand where infection was first recognised in 2017. The decision was made to cull infected and contact cattle when the number of infected farms was low but now remains increasingly challenging though still feasible according to Technical Advisory Group in 2019 [25] because of the high number of infected farms traced subsequently. To date over 2000 infected farms have been traced, although most without clinical or gross pathological signs. Detecting infected farms proved difficult at first because of the use of relatively insensitive diagnostic tests, but now serological ELISA testing bulk tank milk is being used in parallel with real-time PCRs. This has increased confidence that eradication can be achieved, although the process is likely to take at least 5 years or maybe longer.

In Finland, there is a voluntary M. bovis control program (Animal Health ETT) for cattle farms since 2013, which four years later associated $75 \%$ of all dairy farms $[2,23]$.

Pasteurisation or heat treatment is one of proposals to eliminate the risk of $M$. bovis shedding via colostrum or raw milk. Another alternative may be to avoid pooling of colostrum within endemically infected farms, discarding colostrum originating from M. bovis affected cows, or colostrum purchasing 
as replacer [27]. As previously documented, a commercial on-farm pasteurizer was able to destroy Mycoplasma spp. tested in $71.7^{\circ} \mathrm{C}$ for $15 \mathrm{~s}$, including M. bovis. Additional data showed an average $25 \%$ reduction in total immunoglobulin concentration in colostrum after 30 min pasteurization, from $22 \%$ at the low temperature range $\left(63.9-66.7^{\circ} \mathrm{C}\right)$ to $27 \%$ at high temperatures $\left(68.3-70.8^{\circ} \mathrm{C}\right)$ [80]. However, heat treatment of colostrum may affect cytokine absorption and immune response in neonatal calves. A reduction in the circulating IL-1 $\beta$ in dairy calves fed colostrum heat-treated to $60{ }^{\circ} \mathrm{C}$ for $60 \mathrm{~min}$ was demonstrated, although without affecting other immune parameters tested such as IFN- $\gamma$ or IgG concentrations [81].

The generally recommended rule to control subclinical intramammary infections due to M. bovis is sampling of cows with high somatic cell counts (SCC) in milk; however, as was shown in some studies, cows with no clinical signs of mastitis and low SCCs $(<200,000$ cells/mL) can be M. bovis positive $[13,82]$. However, these differences may be a result of the disease stage. The study of Kauf et al. [83] showed that infusion of a mastitic $M$. bovis strain in one quarter of ten first-lactation cows with milk SCCs of $<200,000$ cells/mL caused initial increase in mean milk SCCs within 66 h post infusion. During the study period, the SCC counts fluctuated, with a peak value of $119.82 \times 10^{6}$ cells $/ \mathrm{mL}$ at $90 \mathrm{~h}$ following the infusion; however, they persisted at a higher level than the control until the end of the study at $240 \mathrm{~h}$ post infection [83].

It was recommended that clinically affected $M$. bovis cows should be separated and moved from the main milking group to hospital or another group to prevent the infection spread in the herd. According to the author's opinion, cows within main milking group should be constantly monitored via bulk tank milk testing [13]. However, there was evidence of $M$. bovis mastitis incidence and transmission in the hospital pen following the introduction of cows with $M$. bovis clinical mastitis from three different milking pens, which should not be underestimated [84]. Bulk tank milk testing seems to be effective due to previously reported mycoplasma shedding via milk of cows with mastitis at above $1 \times 10^{6} \mathrm{CFU} / \mathrm{mL}$ [4]. It was suggested that if a positive result is obtained in bulk tank milk testing, it is a good strategy to follow up with pooled milk samples from five cows to identify the individuals [85]. However, SCC screening in bulk tank milk for M. bovis infection control does not appear to be effective [13]. An important suggestion for programs designed for M. bovis mastitis control is milk testing of newly introduced animals into the lactating herd. Additionally, using antibiotics to treat $M$. bovis mastitis should be discouraged [4].

One recommendation for $M$. bovis control programs is to combine regular monitoring of mastitic cows and pneumonia calves with bulk tank milk testing and longitudinal screening of young stock in herds [23].

Another option in the prevention/eradication of $M$. bovis infections is farm sanitization using effective disinfectants. Only a few studies on disinfectant efficacy in inactivating M. bovis has been undertaken. The most recent study estimated the efficacy of different dilutions of citric acid and sodium hypochlorite against $M$. bovis. The results showed that the acceptance criterion for an effective disinfectant of $10^{6}$ fold reduction in the M. bovis viability was met for $0.5 \%$ citric acid and $1 \%$ sodium hypochlorite in the presence of organic material. However, in the absence of organic material, a $10^{6}$ fold reduction in the $M$. bovis viability was observed for $0.25 \%$ citric acid and $0.04 \%$ sodium hypochlorite [86]. In another study, the efficacy of five different classes of teat dips were tested against $M$. bovis in the context of their use in maintaining pre- and post-milking hygiene and preventing M. bovis mastitis. All of them showed germicidal activity against $M$. bovis, but the iodine-based formulation was the most effective in this study [87].

To reduce the risk of $M$. bovis shedding in semen, it is worth paying more attention to the type and volume of antibiotics added to seminal extenders, because currently used mixtures have a more bacteriostatic rather than bactericidal effect on $M$. bovis. According to the author, the antibiotic combination in seminal extenders should be re-evaluated or alternatively M. bovis testing in processed semen should be performed [2]. 
Above all, it is important to recognize the subclinically infected cattle, which can be facilitated by regular monitoring/screening of different age groups of animals using various methods to prevent uncontrolled M. bovis shedding [23].

In summary, $M$. bovis infections are difficult to control/eradicate most of all due to the intracellular nature of the pathogen and biofilm production, which effectively hamper disease treatment. Additionally, increasing trends in antimicrobial resistance of field M. bovis isolates reduce the effectiveness of the therapy used routinely for M. bovis infections. The high genetic and antigenic variability of field M. bovis strains makes them easier to avoid the host immune response. In addition, the general chronic nature of the disease facilitates the spread of the mycoplasma in the herd. Additionally, the lack of effective vaccines makes the eradication of $M$. bovis infections very difficult from cattle population. The relentless and silent spread of $M$. bovis into the infection-free areas is also a feature of this disease. Therefore, regular monitoring/screening of different age groups of animals should be applied, especially for early detection of subclinical carriers in cattle herds; work is also required to develop effective vaccines to provide suitable control of $M$. bovis infections. Finally, there is also an urgent need to develop uniform recommendations that will be included in the programs designed for $M$. bovis infection control.

Author Contributions: Conceptualization, K.D.; writing-original draft preparation, K.D., R.A.J.N., E.S.; writing-review and editing, D.B. All authors have read and agreed to the published version of the manuscript.

Funding: This research received no external funding.

Conflicts of Interest: The authors declare no conflict of interest.

\section{References}

1. Ministry for Primary Industries. First Case of Mycoplasma Bovis Found in Bay of Plenty. 2017. Available online: https://www.tvnz.co.nz/one-news/new-zealand/first-case-mycoplasma-bovis-found-in-bay-plenty (accessed on 20 June 2020).

2. Haapala, V.; Pohjanvirta, T.; Vähänikkilä, N.; Halkilahti, J; Simonen, H.; Pelkonen, S.; Soveri, T.; Simojoki, H.; Autio, T. Semen as a source of Mycoplasma bovis mastitis in dairy herds. Vet. Microbiol. 2018, 216, 60-66. [CrossRef] [PubMed]

3. Nicholas, R.; Ayling, R.; McAuliffe, L. Mycoplasma Diseases of Ruminants, 1st ed.; CABI Publishing: Oxford, UK, 2008.

4. Nicholas, R.A.J.; Fox, L.K.; Lysnyansky, I. Mycoplasma mastitis in cattle: To cull or not to cull. Vet. J. 2016, 216, 142-147. [CrossRef] [PubMed]

5. Klein, U.; de Jong, A.; Youala, M.; El Garch, F.; Stevenin, C.; Moyaert, H.; Rose, M.; Catania, S.; Gyuranecz, M.; Pridmore, A.; et al. New antimicrobial susceptibility data from monitoring of Mycoplasma bovis isolated in Europe. Vet. Microbiol. 2019, 238, 108432. [CrossRef] [PubMed]

6. Houlihan, M.G.; Veenstra, B.; Christian, M.K.; Nicholas, R.; Ayling, R. Mastitis and arthritis in two dairy herds caused by Mycoplasma bovis. Vet. Rec. 2007, 160, 126-127. [CrossRef]

7. Maeda, T.; Shibahara, T.; Kimura, K.; Wada, Y.; Sato, K.; Imada, Y.; Ishikawa, Y.; Kadota, K. Mycoplasma bovis-associated suppurative otitis media and pneumonia in bull calves. J. Comp. Pathol. 2003, 129, 100-110. [CrossRef]

8. Alberti, A.; Filippa Addis, M.; Chessa, B.; Cubeddu, T.; Profiti, M.; Rosati, S.; Ruiu, A.; Pittau, M. Molecular and antigenic characterization of a Mycoplasma bovis strain causing an outbreak of infectious keratoconjunctivitis. J. Vet. Diagn. Invest. 2006, 18, 41-51. [CrossRef]

9. Kinde, H.; Daft, B.M.; Walker, R.L.; Charlton, B.R.; Petty, R. Mycoplasma bovis associated with decubital abscesses in Holstein calves. J. Vet. Diagn. Invest. 1993, 5, 194-197. [CrossRef]

10. Kanda, T.; Tanaka, S.; Suwanruengsri, M.; Sukmawinata, E.; Uemura, R.; Yamaguchi, R.; Sueyoshi, M. Bovine Endocarditis Associated with Mycoplasma bovis. J. Comp. Pathol. 2019, 171, 53-58. [CrossRef]

11. Pardon, B.; Callens, J.; Maris, J.; Allais, L.; Van Praet, W.; Deprez, P.; Ribbens, S. Pathogen-specific risk factors in acute outbreaks of respiratory disease in calves. J. Dairy Sci. 2020, 103, 2556-2566. [CrossRef] 
12. Oliveira, T.E.S.; Pelaquim, I.F.; Flores, E.F.; Massi, R.P.; Valdiviezo, M.J.J.; Pretto-Giordano, L.G.; Alfieri, A.A.; Saut, J.P.E.; Headley, S.A. Mycoplasma bovis and viral agents associated with the development of bovine respiratory disease in adult dairy cows. Transbound. Emerg. Dis. 2019, 67, 82-93. [CrossRef]

13. Hazelton, M.S.; Morton, J.M.; Parker, A.M.; Sheehy, P.A.; Bosward, K.L.; Malmo, J.; House, J.K. Whole dairy herd sampling to detect subclinical intramammary Mycoplasma bovis infection after clinical mastitis outbreaks. Vet. Microbiol. 2020, 244, 108662. [CrossRef] [PubMed]

14. Punyapornwithaya, V.; Fox, L.K.; Hancock, D.D.; Gay, J.M.; Alldredge, J.R. Association between an outbreak strain causing mycoplasma bovis mastitis and its asymptomatic carriage in the herd: A case study from Idaho, USA. Prev. Vet. Med. 2010, 93, 66-70. [CrossRef] [PubMed]

15. Ayling, R.D.; Rosales, R.S.; Barden, G.; Gosney, F.L. Changes in antimicrobial susceptibility of Mycoplasma bovis isolates from Great Britain. Vet. Rec. 2014, 175, 486. [CrossRef] [PubMed]

16. Gautier-Bouchardon, A.V.; Ferré, S.; Le Grand, D.; Paoli, A.; Gay, E.; Poumarat, F. Overall decrease in the susceptibility of Mycoplasma bovis to antimicrobials over the past 30 years in France. PLoS ONE 2014, 9, e87672. [CrossRef]

17. Sulyok, K.M.; Kreizinger, Z.; Fekete, L.; Hrivnák, V.; Magyar, T.; Jánosi, S.; Schweitzer, N.; Turcsányi, I.; Makrai, L.; Erdélyi, K.; et al. Antibiotic susceptibility profiles of Mycoplasma bovis strains isolated from cattle in Hungary, Central Europe. BMC Vet. Res. 2014, 10, 256. [CrossRef]

18. Ayling, R.D.; Baker, S.E.; Peek, M.L.; Simon, A.J.; Nicholas, R.A.J. Comparison of in vitro activity of danofloxacin, florfenicol, oxytetracycline, spectinomycin and tilmicosin against recent field isolates of Mycoplasma bovis. Vet. Rec. 2000, 146, 745-747. [CrossRef]

19. Dudek, K.; Bednarek, D.; Ayling, R.D.; Kycko, A.; Reichert, M. Preliminary study on the effects of enrofloxacin, flunixin meglumine and pegbovigrastim on Mycoplasma bovis pneumonia. BMC Vet. Res. 2019, 15, 371. [CrossRef]

20. Ridley, A.; Hateley, G. Mycoplasma bovis investigations in cattle. Vet. Rec. 2018, 183, 256-258.

21. Dudek, K.; Bednarek, D.; Ayling, R.D.; Kycko, A.; Szacawa, E.; Karpińska, T.A. An experimental vaccine composed of two adjuvants gives protection against Mycoplasma bovis in calves. Vaccine 2016, 34, 3051-3058. [CrossRef]

22. Nicholas, R.A.; Ayling, R.D.; Stipkovits, L.P. An experimental vaccine for calf pneumonia caused by Mycoplasma bovis: Clinical, cultural, serological and pathological findings. Vaccine 2002, 20, 3569-3575. [CrossRef]

23. Vähänikkilä, N.; Pohjanvirta, T.; Haapala, V.; Simojoki, H.; Soveri, T.; Browning, G.F.; Pelkonen, S.; Wawegama, N.K.; Autio, T. Characterisation of the course of Mycoplasma bovis infection in naturally infected dairy herds. Vet. Microbiol. 2019, 231, 107-115. [CrossRef] [PubMed]

24. Nicholas, R.A. Bovine mycoplasmosis: Silent and deadly. Vet. Rec. 2011, 168, 459-462. [CrossRef] [PubMed]

25. Technical Advisory Group (TAG) Report. 2019. Available online: https://www.mpi.govt.nz/dmsdocument/ 37754-report-of-the-mycoplasma-bovis-technical-advisory-group-tag-in-response-to-the-terms-ofreference-june-2019-18-october-2019 (accessed on 5 August 2020).

26. Timonen, A.A.E.; Autio, T.; Pohjanvirta, T.; Häkkinen, L.; Katholm, J.; Petersen, A.; Mõtus, K.; Kalmus, P. Dynamics of the within-herd prevalence of Mycoplasma bovis intramammary infection in endemically infected dairy herds. Vet. Microbiol. 2020, 242, 108608. [CrossRef] [PubMed]

27. Gille, L.; Evrard, J.; Callens, J.; Supré, K.; Grégoire, F.; Boyen, F.; Haesebrouck, F.; Deprez, P.; Pardon, B. The presence of Mycoplasma bovis in colostrum. Vet. Res. 2020, 51, 54. [CrossRef]

28. Passchyn, P.; Piepers, S.; De Meulemeester, L.; Boyen, F.; Haesebrouck, F.; De Vliegher, S. Between-herd prevalence of Mycoplasma bovis in bulk milk in Flanders, Belgium. Res. Vet. Sci. 2012, 92, 219-220. [CrossRef]

29. Stott, G.H.; Wiersma, F.; Menefee, B.E.; Radwanski, F.R. Influence of environment on passive immunity in calves. J. Dairy Sci. 1976, 59, 1306-1311. [CrossRef]

30. Alabdullah, H.; Schneider, C.; Fox, L. Effect of dexamethasone administration on shedding of Mycoplasma bovis in calves. In Proceedings of the Third International Symposium on Mastitis and Milk Quality, St. Louis, MO, USA, 22-24 September 2011.

31. Alabdullah, H.A.; Fox, L.K.; Gay, J.M.; Barrington, G.M.; Mealey, R.H. Effects of dexamethasone and Mycoplasma bovis on bovine neutrophil function in vitro. Vet. Immunol. Immunopathol. 2015, 164, 67-73. [CrossRef]

32. Ayling, R.D.; Bashiruddin, S.E.; Nicholas, R.A.J. Mycoplasma species and related organisms isolated from ruminants in Britain between 1990 and 2000. Vet. Rec. 2004, 155, 413-416. [CrossRef] 
33. Gagea, M.I.; Bateman, K.G.; Shanahan, R.A.; van Dreumel, T.; McEwen, B.J.; Carman, S.; Archambault, M.; Caswell, J.L. Naturally occurring Mycoplasma bovis-associated pneumonia and polyarthritis in feedlot beef calves. J. Vet. Diagn. Invest. 2006, 18, 29-40. [CrossRef]

34. Ryan, M.J.; Wyand, D.S.; Hill, D.L.; Tourtellotte, M.E.; Yang, T.J. Morphologic changes following intraarticular inoculation of Mycoplasma bovis in calves. Vet. Pathol. 1983, 20, 472-487. [CrossRef]

35. Foster, A.P.; Naylor, R.D.; Howie, N.M.; Nicholas, R.A.; Ayling, R.D. Mycoplasma bovis and otitis in dairy calves in the United Kingdom. Vet. J. 2009, 179, 455-457. [CrossRef] [PubMed]

36. Ayling, R.; Nicholas, R.; Hogg, R.; Wessels, J.; Scholes, S.; Byrne, W.; Hill, M.; Moriarty, J.; O’Brien, T. Mycoplasma bovis isolated from brain tissue of calves. Vet. Rec. 2005, 156, 391-392. [CrossRef] [PubMed]

37. Kanci, A.; Wawegama, N.K.; Marenda, M.S.; Mansell, P.D.; Browning, G.F.; Markham, P.F. Reproduction of respiratory mycoplasmosis in calves by exposure to an aerosolised culture of Mycoplasma bovis. Vet. Microbiol. 2017, 210, 167-173. [CrossRef] [PubMed]

38. Jasper, D.E.; Al-Aubaidi, J.M.; Fabricant, J. Epidemiologic observations on mycoplasma mastitis. Cornell Vet. 1974, 64, 407-415.

39. Maunsell, F.P.; Woolums, A.R.; Francoz, D.; Rosenbush, R.F.; Step, D.L.; Wilson, D.J.; Janzen, E.D. Mycoplasma bovis infections in cattle. ACVIM Consensus Statement. J. Vet. Intern. Med. 2011, 25, 772-783. [CrossRef]

40. Lysnyansky, I.; Freed, M.; Rosales, R.S.; Mikula, I.; Khateb, N.; Gerchman, I.; van Straten, M.; Levisohn, S. An overview of Mycoplasma bovis mastitis in Israel (2004-2014). Vet. J. 2016, 207, 180-183. [CrossRef]

41. Hermeyer, K.; Peters, M.; Brügmann, M.; Jacobsen, B.; Hewicker-Trautwein, M. Demonstration of Mycoplasma bovis by immunohistochemistry and in situ hybridization in an aborted bovine fetus and neonatal calf. J. Vet. Diagn. Invest. 2012, 24, 364-369. [CrossRef]

42. Pfützner, H.; Sachse, K. Mycoplasma bovis as an agent of mastitis, pneumonia, arthritis and genital disorders in cattle. Rev. Sci. Tech. Off. Int. Epiz. 1996, 15, 1477-1494. [CrossRef]

43. Poumarat, F.; Longchambon, D.; Martel, J.L. Application of dot immunobinding on membrane filtration (MF dot) to the study of relationships within "M. mycoides cluster" and within "glucose and arginine-negative cluster" of ruminant mycoplasmas. Vet. Microbiol. 1992, 32, 375-390. [CrossRef]

44. Nicholas, R.A.J.; Baker, S.E. Recovery of mycoplasmas from animals. In Mycoplasma Protocols; Miles, R.J., Nicholas, R.A.J., Eds.; Humana Press: Totowa, NJ, USA, 1998; pp. 37-44.

45. Behera, S.; Rana, R.; Gupta, P.K.; Kumar, D.; Sonal; Rekha, V.; Arun, T.R.; Jena, D. Development of real-time PCR assay for the detection of Mycoplasma bovis. Trop. Anim. Health Prod. 2018, 50, 875-882. [CrossRef]

46. Andrés-Lasheras, S.; Zaheer, R.; Ha, R.; Lee, C.; Jelinski, M.; McAllister, T.A. A direct qPCR screening approach to improve the efficiency of Mycoplasma bovis isolation in the frame of a broad surveillance study. J. Microbiol. Methods 2020, 169, 105805. [CrossRef] [PubMed]

47. Appelt, S.; Aly, S.S.; Tonooka, K.; Glenn, K.; Xue, Z.; Lehenbauer, T.W.; Marco, M.L. Development and comparison of loop-mediated isothermal amplification and quantitative polymerase chain reaction assays for the detection of Mycoplasma bovis in milk. J. Dairy Sci. 2019, 102, 1985-1996. [CrossRef] [PubMed]

48. Parker, A.M.; House, J.K.; Hazelton, M.S.; Bosward, K.L.; Sheehy, P.A. Comparison of culture and a multiplex probe PCR for identifying Mycoplasma species in bovine milk, semen and swab samples. PLoS ONE 2017, 12, e0173422. [CrossRef] [PubMed]

49. Pansri, P.; Katholm, J.; Krogh, K.M.; Aagaard, A.K.; Schmidt, L.M.B.; Kudirkiene, E.; Larsen, L.E.; Olsen, J.E. Evaluation of novel multiplex qPCR assays for diagnosis of pathogens associated with the bovine respiratory disease complex. Vet. J. 2020, 256, 105425. [CrossRef] [PubMed]

50. Conrad, C.C.; Daher, R.K.; Stanford, K.; Amoako, K.K.; Boissinot, M.; Bergeron, M.G.; Alexander, T.; Cook, S.; Ralston, B.; Zaheer, R.; et al. A Sensitive and Accurate Recombinase Polymerase Amplification Assay for Detection of the Primary Bacterial Pathogens Causing Bovine Respiratory Disease. Front. Vet. Sci. 2020, 7, 208. [CrossRef] [PubMed]

51. Ashraf, A.; Imran, M.; Yaqub, T.; Tayyab, M.; Shehzad, W.; Mingala, C.N.; Chang, Y.-F. Development and validation of a loop-mediated isothermal amplification assay for the detection of Mycoplasma bovis in mastitic milk. Folia Microb. 2018, 63, 373-380. [CrossRef]

52. Itoh, M.; Hirano, Y.; Yamakawa, K.; Yasutomi, I.; Kuramoto, K.; Furuok, M.; Yamada, K. Combination of procedure for ultra rapid extraction (PURE) and loop-mediated isothermal amplification (LAMP) for rapid detection of Mycoplasma bovis in milk. J. Vet. Med. Sci. 2020, 19-0695. [CrossRef] 
53. Zhao, G.; Hou, P.; Huan, Y.; He, C.; Wang, H.; He, H. Development of a recombinase polymerase amplification combined with a lateral flow dipstick assay for rapid detection of the Mycoplasma bovis. BMC Vet. Res. 2018, 14, 412. [CrossRef]

54. Bokma, J.; Van Driessche, L.; Deprez, P.; Haesebrouck, F.; Vahl, M.; Weesendorp, E.; Deurenberg, R.H.; Pardon, P.; Boyen, P. Rapid identification of 1 Mycoplasma bovis from bovine bronchoalveolar lavage fluid with MALDI-TOF MS after enrichment procedure. J. Clin. Microbiol. 2020, 58, e00004-20. [CrossRef]

55. Thurmond, M.C.; Tyler, J.W.; Luiz, D.M.; Holmberg, C.A.; Picanso, J.P. The effect of pre-enrichment on recovery of Streptococcus agalactiae, Staphylococcus aureus and mycoplasma from bovine milk. Epidemiol. Infect. 1989, 103, 465-474. [CrossRef]

56. Punyapornwithaya, V.; Fox, L.K.; Gay, G.M.; Hancock, D.D.; Alldredge, J.R. Short communication: The effect of centrifugation and resuspension on the recovery of Mycoplasma species from milk. J. Dairy Sci. 2009, 92, 4444-4447. [CrossRef] [PubMed]

57. Li, Y.; Fan, P.; Zhou, S.; Zhang, L. Loop-mediated isothermal amplification (LAMP): A novel rapid detection platform for pathogens. Microb. Pathog. 2017, 107, 54-61. [CrossRef] [PubMed]

58. Nunoya, T.; Omori, T.; Tomioka, H.; Umeda, F.; Suzuki, T.; Uetsuka, K. Intracellular Localization of Mycoplasma bovis in the Bronchiolar Epithelium of Experimentally Infected Calves. J. Comp. Path. 2020, 176, 14-18. [CrossRef] [PubMed]

59. Kleinschmidt, S.; Spergser, J.; Rosengarten, R.; Hewicker-Trautwein, M. Long-term survival of Mycoplasma bovis in necrotic lesions and in phagocytic cells as demonstrated by transmission and immunogold electron microscopy in lung tissue from experimentally infected calves. Vet. Microbiol. 2013, 162, 949-953. [CrossRef] [PubMed]

60. Bell-Rogers, P.; Parker, L.; Cai, H.Y. Multi-locus sequence types of Mycoplasma bovis isolated from Ontario, Canada in the past three decades have a temporal distribution. J. Vet. Diagn. Invest. 2018, 30, 130-135. [CrossRef]

61. Register, K.B.; Lysnyansky, I.; Jelinski, M.D.; Boatwright, W.D.; Waldner, M.; Bayles, D.O.; Pilo, P.; Alt, D.P. Comparison of two multilocus sequence typing schemes for Mycoplasma bovis and revision of the PubMLST reference method. J. Clin. Microbiol. 2020, 58, e00283-20. [CrossRef]

62. Yair, Y.; Borovok, I.; Mikula, I.; Falk, R.; Fox, L.K.; Gophna, U.; Lysnyansky, I. Genomics-based epidemiology of bovine Mycoplasma bovis strains in Israel. BMC Genom. 2020, 21, 70. [CrossRef]

63. Parker, A.M.; Shukla, A.; House, J.K.; Hazelton, M.S.; Bosward, K.L.; Kokotovic, B.; Sheehy, P.A. Genetic characterization of Australian Mycoplasma bovis isolates through whole genome sequencing analysis. Vet. Microbiol. 2016, 196I, 118-125. [CrossRef]

64. Rasheed, M.A.; Qi, J.; Zhu, X.; Chenfei, H.; Menghwar, H.; Khan, F.A.; Guo, A. Comparative genomics of Mycoplasma bovis strains reveals that decreased virulence with increasing passages might correlate with potential virulence-related factors. Front. Cell. Infect. Microbiol. 2017, 7, 177. [CrossRef]

65. Sachse, K.; Pfützner, H.; Hötzel, H.; Demuth, B.; Heller, M.; Berthold, E. Comparison of various diagnostic methods for the detection of Mycoplasma bovis. Rev. Sci. Tech.-Off. Int. Epiz. 1993, 12, 571-580. [CrossRef]

66. Nielsen, P.K.; Petersen, M.B.; Nielsen, L.R.; Halasa, T.; Toft, N. Latent class analysis of bulk tank milk PCR and ELISA testing for herd level diagnosis of Mycoplasma bovis. Prev. Vet. Med. 2015, 121, 338-342. [CrossRef] [PubMed]

67. Gille, L.; Callens, J.; Supré, K.; Boyen, F.; Haesebrouck, F.; Van Driessche, L.; van Leenen, K.; Deprez, P.; Pardon, B. Use of breeding bull and absence of a calving pen as a risk factors for the presence of Mycoplasma bovis in dairy herds. J. Dairy Sci. 2018, 101, 8284-8290. [CrossRef] [PubMed]

68. Andersson, A.-M.; Aspán, A.; Wisselink, H.J.; Smid, B.; Ridley, A.; Pelkonen, S.; Autio, T.; Lauritsen, K.T.; Kensø, J.; Gaurivaud, P.; et al. A European inter-laboratory trial to evaluate the performance of three serological methods for diagnosis of Mycoplasma bovis infection in cattle using latent class analysis. BMC Vet. Res. 2019, 15, 369. [CrossRef] [PubMed]

69. Wawegama, N.K.; Browning, G.F.; Kanci, A.; Marenda, M.S.; Markham, F.F. Development of a Recombinant Protein-Based Enzyme-Linked Immunosorbent Assay for Diagnosis of Mycoplasma bovis Infection in Cattle. Clin. Vaccine Immunol. 2014, 21, 196-202. [CrossRef] [PubMed]

70. Petersen, M.B.; Wawegama, N.K.; Denwood, M.; Markham, P.F.; Browning, G.F.; Nielsen, L.R. Mycoplasma bovis antibody dynamics in naturally exposed dairy calves according to two diagnostic tests. BMC Vet. Res. 2018, 14, 258. [CrossRef] [PubMed] 
71. Wisselink, H.J.; Smid, B.; Plater, J.; Ridley, A.; Andersson, A.-M.; Aspán, A.; Pohjanvirta, T.; Vähänikkilä, N.; Larsen, H.; Høgberg, J.; et al. A European interlaboratory trial to evaluate the performance of different PCR methods for Mycoplasma bovis diagnosis. BMC Vet. Res. 2019, 15, 86. [CrossRef]

72. Chazel, M.; Tardy, F.; Le Grand, D.; Calavas, D.; Poumarat, F. Mycoplasmoses of ruminants in France: Recent data from the national surveillance network. BMC Vet. Res. 2010, 6, 32. [CrossRef]

73. Mackie, D.P.; Finley, D.; Brice, N.; Ball, H.J. Mixed mycoplasma mastitis outbreak in a dairy herd. Vet. Rec. 2000, 147, 335-336. [CrossRef]

74. Jasper, D.E. Prevalence of mycoplasmal mastitis in the western states. Calif. Vet. 1980, 43, $24-26$.

75. McAuliffe, L.; Ellis, R.J.; Lawes, J.R.; Ayling, R.D.; Nicholas, R.A.J. 16S rDNA PCR and denaturing gradient gel electrophoresis; a single generic test for detecting and differentiating Mycoplasma species. J. Med. Microbiol. 2005, 54, 731-739. [CrossRef]

76. Loy, J.D.; Leger, L.; Workman, A.M.; Clawson, M.L.; Bulut, E.; Wang, B. Development of a multiplex real-time PCR assay using two thermocycling platforms for detection of major bacterial pathogens associated with bovine respiratory disease complex from clinical samples. J. Vet. Diagn. Invest. 2018, 30, 837-847. [CrossRef] [PubMed]

77. Pereyre, S.; Tardy, F.; Renaudin, H.; Cauvin, E.; Del Prá Netto Machado, L.; Tricot, A.; Benoit, F.; Treilles, M.; Bébéar, C. Identification and Subtyping of Clinically Relevant Human and Ruminant Mycoplasmas by Use of Matrix-Assisted Laser Desorption Ionization-Time of Flight Mass Spectrometry J. Clin. Microbiol. 2013, 51, 3314-3323. [CrossRef] [PubMed]

78. O'Farrell, K.; Dillon, P.; Mee, j.; Crosse, S.; Nnolan, M.; Byrne, N.; Reidy, M.; Flynn, F.; Condon, T. Strategy for restocking Moorepark after depopulation following BSE. Ir. Vet. J. 2001, 54, 70-75.

79. Lysnyansky, I.; Mikula, I.; Ozeri, R.; Bellaiche, M.; Nicholas, R.A.J.; van Straten, M. Mycoplasma bovis Seroprevalence in Israeli Dairy Herds, Feedlots and Imported Cattle. Isr. J. Vet. Med. 2017, 72, 13-16.

80. Stabel, J.R.; Hurd, S.; Calvente, L.; Rosenbusch, R.F. Destruction of Mycobacterium paratuberculosis, Salmonella spp., and Mycoplasma spp. in raw milk by a commercial on-farm high-temperature, short-time pasteurizer. J. Dairy Sci. 2004, 87, 2177-2183. [CrossRef]

81. Gelsinger, S.L.; Heinrichs, A.J. Comparison of immune responses in calves fed heat-treated or unheated colostrum. J. Dairy Sci. 2017, 100, 4090-4101. [CrossRef] [PubMed]

82. Higuchi, H.; Gondaira, S.; Iwano, H.; Hirose, K.; Nakajima, K.; Kawai, K.; Hagiwara, K.; Tamura, Y.; Nagahata, H. Mycoplasma species isolated from intramammary infection of Japanese dairy cows. Vet. Rec. 2013, 172, 557. [CrossRef]

83. Kauf, A.C.; Rosenbusch, R.F.; Paape, M.J.; Bannerman, D.D. Innate immune response to intramammary Mycoplasma bovis infection. J. Dairy Sci. 2007, 90, 3336-3348. [CrossRef]

84. Punyapornwithaya, V.; Fox, L.K.; Hancock, D.D.; Gay, J.M.; Wenz, J.R.; Alldredge, J.R. Incidence and transmission of Mycoplasma bovis mastitis in Holstein dairy cows in a hospital pen: A case study. Prev. Vet. Med. 2011, 98, 74-78. [CrossRef]

85. Murai, K.; Lehenbauer, T.W.; Champagne, J.D.; Glenn, K.; Aly, S.S. Cost-effectiveness of diagnostic strategies using quantitative real-time PCR and bacterial culture to identify contagious mastitis cases in large dairy herds. Prev. Vet. Med. 2014, 113, 522-535. [CrossRef]

86. Mahdizadeh, S.; Sawford, K.; van Andel, M.; Browning, G.F. Efficacy of citric acid and sodium hypochlorite as disinfectants against Mycoplasma bovis. Vet. Microbiol. 2020, 243, 108630. [CrossRef] [PubMed]

87. Boddie, R.L.; Owens, W.E.; Ray, C.H.; Nickerson, S.C.; Boddie, N.T. Germicidal activities of representatives of five different teat dip classes against three bovine mycoplasma species using a modified excised teat model. J. Dairy Sci. 2002, 85, 1909-1912. [CrossRef]

(C) 2020 by the authors. Licensee MDPI, Basel, Switzerland. This article is an open access article distributed under the terms and conditions of the Creative Commons Attribution (CC BY) license (http://creativecommons.org/licenses/by/4.0/). 